\title{
Enzyme Electrophoresis, Catalase Test and PCR-RFLP Analysis for the Typing of Edwardsiella tarda
}

\author{
Yoshiyuki Yamada and Hisatsugu Wakabayashi \\ Department of Aquatic Bioscience, Graduate School of Agricultural and Life Sciences, \\ The University of Tokyo, Yayoi 1-1-1, Bunkyo-ku, Tokyo 113-8657, Japan
}

(Received September 1, 1997)

\begin{abstract}
Enzyme electrophoresis for superoxide dismutase (SOD) and catalase divided 144 Edwardsiella tarda strains into two groups; group 1 contained all the strains isolated from diseased fish in Japan and group 2 included 25 strains from non-disease sources and reference strain ATCC $15947^{\mathrm{T}}$. These groups could be similarly distinguished by a simple catalase test; group 1 showed an instantaneous bubbling, whereas in group 2 bubbling was delayed or weak. PCR-RFLP analysis using HhaI revealed that the two groups differed in their 16S rDNA genotypes. Furthermore, this analysis subdivided group 1 into two genotypes.
\end{abstract}

Keywords: Edwardsiella tarda, SOD, catalase, 16S rDNA, enzyme electrophoresis, PCR, RFLP

Edwardsiellosis, caused by Edwardsiella tarda, has long been recognized as a common bacterial disease in freshwater and marine fish in Japan (Wakabayashi and Egusa, 1973; Kusuda et al., 1976; Kubota et al., 1981; Nakatsugawa, 1983).

Epidemiological surveys of E. tarda in Japan revealed that isolates from diseased fish and their environments (eel ponds) were classified into several different serotypes (A, B, C, D and unclassified), with most of the strains belonging to type $A$ being virulent against fish (Park et al., 1983, Rashid et al., 1994). Serotyping has been one of the popular methods to type natural populations of bacterial species, but the analysis of the genetic structure of populations has recently been shown to be of great value in the study of variation within species in bacterial population genetics and systematics.

There are several approaches to assaying genetic variation of bacterial populations. Multilocus enzyme electrophoresis has the ability to reveal many variations in enzymes, with regard to their shape, net charge, catalytic efficiency and stability. The differences in these characters result from many aspects of the genetic differences. Hence, in many bacterial species phenotyping reveals the presence of genetic variation (Selander et al., 1986). Inversely in the analysis of DNA, restriction fragment length polymorphysm (RFLP) analysis of PCRamplified DNA is one of the useful technique to compare the DNA sequences based on the distribution of restriction sites. Small subunits ribosomal DNA (16S
rDNA) was the most investigated and valuable tool to discuss the phylogenetic diversities among bacteria and RFLP analysis of PCR-amplified 16S rDNA was used for identification or grouping of bacterial isolates (Schmidt, 1994).

The aim of the present study was the typing of natural populations of $E$. tarda using enzyme electrophoresis, catalase test and PCR-RFLP analysis, and phylogenetic diversities among the populations were also discussed using these typing methods.

\section{Materials and Methods}

\section{Bacteria}

E. tarda ATCC $15947^{\mathrm{T}}$ was purchased from the American Type Culture Collection. Another 143 strains were isolated from diseased fish (Japanese eel, Anguilla japonica; Japanese flounder, Paralichtys olivaceus; Nile tilapia, Oreochromis niloticus; red sea bream, Chrysophrus major; loach, Misgurnus anguillicaudatus and ayu, Plecoglossus altivelis), apparently healthy Japanese eels, or their environments (eel ponds) during the past three decades. Localities of the diseased fish were Aichi, Ehime, Kagoshima, Miyazaki, Nagasaki, Niigata, Oita, Saga, Shizuoka, and Tokushima, whereas isolates from eel ponds were collected in Nagasaki and Shizuoka. The material collected was stored at $-80^{\circ} \mathrm{C}$ in tryptosoya (TS) broth (Nissui co.) containing 10\% (v/v) glycerol until use. 


\section{Enzyme Electrophoresis}

Each strain was cultured on TS agar at $25^{\circ} \mathrm{C}$. Bacterial cells in a stationary phase were collected and suspended in distilled water. Cells were disrupted by sonication and then centrifuged at $16,800 \times g$ for $20 \mathrm{~min}$ at $4^{\circ} \mathrm{C}$. The supernatant was collected and stored at $-80^{\circ} \mathrm{C}$ until required for electrophoresis. A non-denatured polyacrylamide gel electrophoresis (native-PAGE) was performed on $12.5 \%$ or $7.5 \%$ acrylamide gels.

\section{Visualization of SOD and catalase activities}

Superoxide dismutase (SOD) activities on the $12.5 \%$ gels were visualized using nitro blue tetrazolium and riboflavin (Beauchamp et. al., 1971), whereas catalase activities on the $7.5 \%$ gels were visualized using horseradish peroxidase, $\mathrm{H}_{2} \mathrm{O}_{2}$ and diaminobenzidine (Clare $e t$. al., 1984). To estimate the amount of metal contained in each SOD band staining was conducted with the following inhibitors; $3.7 \mathrm{mM} \mathrm{H}_{2} \mathrm{O}_{2}$, and $1.9 \mathrm{mM} \mathrm{KCN}$ (Crapo et al., 1991).

\section{Catalase activity}

Each strain was cultured on TS agar at $25^{\circ} \mathrm{C}$ for $48 \mathrm{~h}$. A single colony was used for a simple catalase test by adding a drop of $3 \% \mathrm{H}_{2} \mathrm{O}_{2}$ to the cells on a glass slide. The time required for the appearance of oxygen bubble was used as an estimation of activity; instantaneous bubbling was recorded as "immediate" and any delayed or weak bubbling was recorded as "delayed" (Chester et al., 1987).

\section{DNA extraction}

Chromosomal DNA of 144 E. tarda strains were prepared by the boiled-extraction method (Aoki et al., 1995). Briefly, this technique involves the bacterial cells suspended in distilled water being boiled at $100^{\circ} \mathrm{C}$ for $10 \mathrm{~min}$. The supernatant containing the template DNA was then obtained by centrifugation at $16,800 \times g$ for 10 $\min$ at $4^{\circ} \mathrm{C}$.

\section{PCR amplification of $16 S$ rDNA}

The oligonucleotide primers used were those designed to anneal to conserved regions of the eubacterial $16 \mathrm{~S}$ rRNA: forward, 5'-AGAGTTTGA-TCCTGGCTCAG-3'; reverse, 5'-GGTTACCTTGTTACGACTT-3' (Weisburg et al., 1991).

PCR amplification was performed with a GeneAmp® PCR System 2400 (Perkin-Elmer Co.) using AmpliTaq Gold $^{\mathrm{TM}}$ polymerase and $10 \times$ PCR buffer (Perkin-Elmer Co.) in a total reaction volume of $50 \mu \mathrm{l}$. This reaction mixture contained $0.1-0.2 \mu \mathrm{g}$ of template DNA (in DW), $20 \mu \mathrm{M}$ of each deoxynucleoside triphosphates, $20 \mathrm{pM}$ of each primer, $1.5 \mathrm{mM} \mathrm{MgCl}_{2}$, and $1.25 \mathrm{U}$ of AmpliTaq Gold $^{\mathrm{TM}}$ DNA polymerase. The following temperature profile was used for the amplification: preheating at $94^{\circ} \mathrm{C}$ for $9 \mathrm{~min}$; 40 cycles of denaturation $\left(94^{\circ} \mathrm{C}, 30 \mathrm{~s}\right)$, annealing $\left(50^{\circ} \mathrm{C}, 30 \mathrm{~s}\right)$, and extention $\left(72^{\circ} \mathrm{C}, 90 \mathrm{~s}\right)$; and a final extention at $72^{\circ} \mathrm{C}$ for $7 \mathrm{~min}$.

\section{Restriction fragment analysis}

Thirty-two representative strains of each type (groups 1 or 2) which were classified according to the enzyme electrophoresis and catalase tests, were used for screening of the appropriate enzyme for the $16 \mathrm{~S}$ rDNA genotyping of E. tarda.

Eight micro-liters of the PCR products were digested with the 2.5 units of restriction endonucleases at $37^{\circ} \mathrm{C}$ for $150 \mathrm{~min}$ according to the manufacturer's instructions. The following 4 and 5 base-cutter enzymes were used: $A l u \mathrm{I}, D d e \mathrm{I}, H i n f \mathrm{I}, R s a \mathrm{I}$ (TOYOBO Co. Ltd.), HhaI (TAKARA Shuzo Co.), HaeIII, MspI, Sau3A (BOEHRINGER MANNHEIM Co.). Restricted DNAs were analyzed by horizontal electrophoresis in $4 \%$ NuSieve 3: 1 agarose gels (FMC Bioproducts Co.). Electrophoresis was carried out at $50 \mathrm{~V}$ for $180 \mathrm{~min}$ using Mupid mini-gel electrophoresis apparatus (Advance Co.) in TAE electrophoresis buffer on ice. DNA fragments were stained by ethidium bromide, and visualized under UV light.

In $H$ haI digestion, which exhibited several different fragment patterns, stability of the identifying fragments was investigated using 5 units of enzyme and extended reaction times (180, $240 \mathrm{~min})$. Then, RFLP analysis using HhaI was performed to the 144 E. tarda strains.

\section{Results}

\section{Enzyme electrophoresis}

Electrophoretic patterns of SOD and catalase are shown in Fig. 1. Electrophoretic mobilities of SOD and catalase divided the 144 E. tarda strains into two groups. Group 1 produced SOD type 1 and catalase type 1 , and consisted of 118 strains. On the other hand, group 2 produced SOD type 2 and catalase type 2 , and consisted of 26 strains. The reference strain ATCC $15947^{\mathrm{T}}$ was classified into group 2 (Table 1). The SOD inhibitors revealed that the metal contained in all strains was iron and hence it was identified as an iron-containing SOD (FeSOD). 

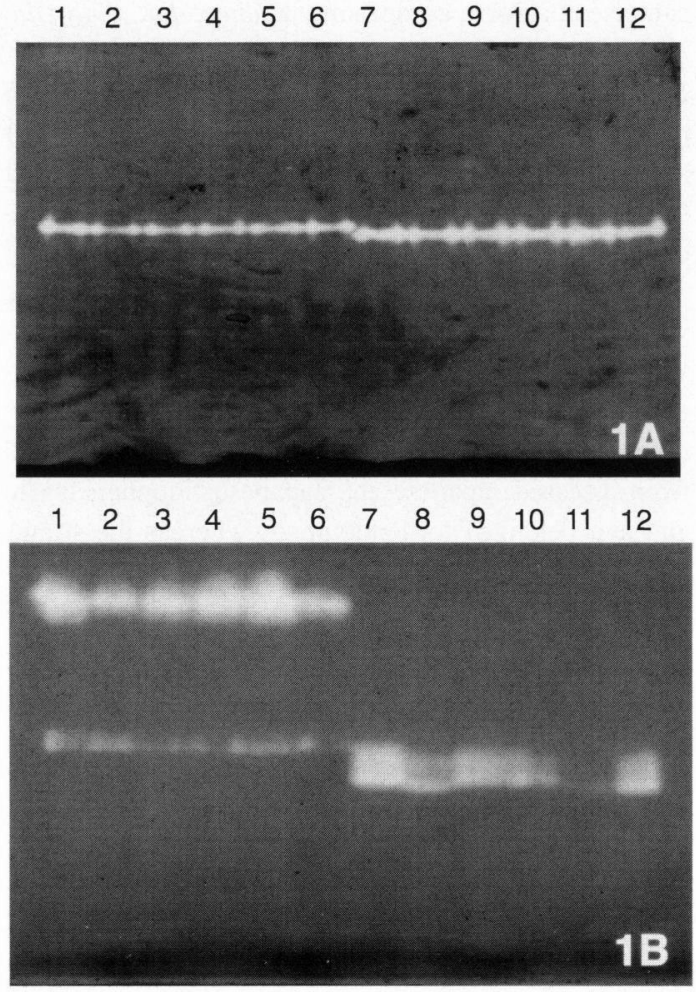

Fig. 1. 1A: Electrophoretic patterns of superoxide dismutase (SOD) on a $12.5 \%$ acrylamide gel. The electrophoretic mobilities of SOD isolated from the E. tarda strains were separated into two types; lanes 1 to 6 were of type 1 , and lanes 7 to 12 were of type 2. 1B: Electrophoretic patterns of catalase isolated from the $E$. tarda strains on a $7.5 \%$ acrylamide gel. Catalase was also separated into two types; lanes 1 to 6 were of type 1 , and lanes 7 to 12 were of type 2 . (The same samples were applied to the same lanes on both gels.)

\section{Catalase test}

The catalase activity of each strain depended on the catalase type. All strains producing catalase type 1 were classified as "immediate", whereas all members producing catalase type 2 were typed as "delayed" (Table 1).

\section{SrDNA PCR-RFLP analysis}

The DNA fragments of the representative 32 strains showed the same pattern following restriction with the enzymes; AluI, DdeI, HaeIII, HinfI, MspI, RsaI and Sau3A (Data not shown). On the other hand, the strains exhibited several different patterns when digested with HhaI (Fig. 2). The genetic variation was typed (genotypes A, B and C) according to the presence or absence of 190, 100 and $90 \mathrm{bp}$ fragments. Several strains of genotype $C$ had an additional band of approximately 470 bp. Due to the weak staining of this band compared to its fragment size, this group was tentatively typed as C'. The identifying fragments of the three genotype were stable under the digestion using 5 units of enzyme and extended reaction times.

The RFLP analysis with HhaI was performed to the 144 E. tarda strains. It split the strains identified as group 1 by the enzyme electrophoresis and catalase test into genotypes A or B, whereas group 2 strains exhibited genotype $\mathrm{C}$ (Tables 1 and 2).

\section{Discussion}

In the present study, the phenotypings made according to the enzyme electrophoresis and catalase test gave a rough understanding of the populations of E. tarda investigated. These tests revealed that the Japanese isolates were divided into two major populations, groups 1 and 2.

The electrophoretic mobilities of enzymes are determined by their structures; i.e, by their amino acid composition (primary structure) and by additional folding and assembly into their secondary and tertiary structures. The variations in electrophoretic migration of FeSOD and catalase of E. tarda strains suggested that structural differences exist between strains in these enzymes or that post-translational modifications to them differ, with the result that groups 1 and 2 were quite different populations.

In a simple catalase test, groups 1 and 2 differed in the time required for the appearance of oxygen bubbles.

Table 1. The phenotyping of E. tarda strains according to enzyme electrophoresis and catalase test, and the relationship of these typings with 16S rDNA genotypes.

\begin{tabular}{|c|c|c|c|c|}
\hline \multirow{2}{*}{$\begin{array}{c}\text { Populations of } \\
\text { E. tarda }\end{array}$} & \multicolumn{2}{|c|}{ Enzyme electrophoresis } & \multirow{2}{*}{$\begin{array}{l}\text { Catalase } \\
\text { test }\end{array}$} & \multirow{2}{*}{$\begin{array}{l}16 \mathrm{~S} \text { rDNA } \\
\text { genotype }\end{array}$} \\
\hline & FeSOD & catalase & & \\
\hline Group 1 (118 strains) & type 1 & type 1 & immediate & $\mathrm{A}, \mathrm{B}$ \\
\hline Group 2 (26 strains) & type 2 & type 2 & delayed & $\mathrm{C}, \mathrm{C}^{\prime}$ \\
\hline
\end{tabular}




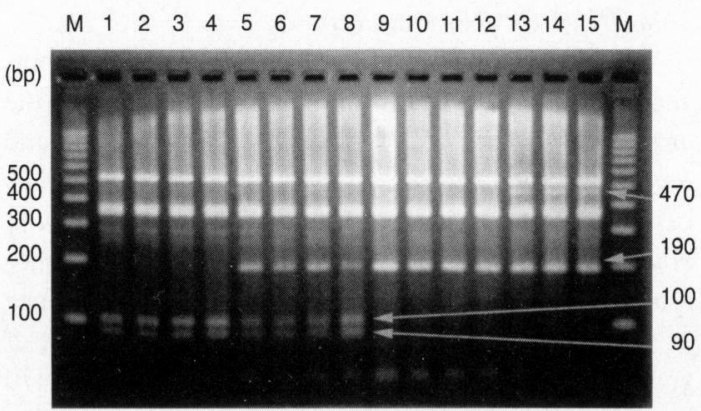

Fig. 2. Restriction fragment length polymorphism (RFLP) patterns of HhaI digested 16S rDNA of representative $E$. tarda strains on a $4 \%$ NuSieve $3: 1$ agarose gel. The genetic variation was typed by the presence or absence of the 190, 100 and $90 \mathrm{bp}$ fragments (see arrows) : genotype A; lanes 1 to 4 , genotype B; lanes 5 to 8 , genotype $\mathrm{C}$; lanes 9 to 15 (lanes 13 to 15 had an additional band of approximately 470bp: C'). M; $100 \mathrm{bp}$ DNA ladder (Laboratories, Inc.)

Table 2. The relationship between $16 \mathrm{~S}$ rDNA genotypes of E. tarda strains as determined by RFLP analysis and the sources of these strains.

\begin{tabular}{lrrrr}
\hline \hline Sources of the strains & \multicolumn{5}{c}{ 16S rDNA genotypes of E. tarda } \\
\cline { 2 - 5 } & A & B & C & C' $^{\prime}$ \\
\hline ATCC15947 & - & - & 1 & - \\
Diseased fish & & & & \\
$\quad$ Japanese eel & 54 & 0 & 0 & 0 \\
Japanese flounder & 37 & 0 & 0 & 0 \\
$\quad$ Red sea bream & 0 & 13 & 0 & 0 \\
Tilapia & 0 & 2 & 0 & 0 \\
Ayu & 2 & 0 & 0 & 0 \\
$\quad$ Loach & 2 & 0 & 0 & 0 \\
Intestinal contents of & 2 & 0 & 5 & 3 \\
$\quad$ apparently healthy eel & & & & \\
Eel culture pond & & & & \\
$\quad$ Water & 5 & 0 & 10 & 1 \\
$\quad$ Sediment & 1 & 0 & 3 & 3 \\
\hline Total 144 strains & 103 & 15 & 19 & 7 \\
\hline
\end{tabular}

Chester et al. (1987) used this semiquantitative method as a supplemental test for rapid identification of members of the family Enterobacteriaceae. According to their survey, the family Enterobacteriaceae was divided into two major groups: "immediate" catalase reactors, comprising Yersinia, Serratia, Proteus, Morganella, Providencia, Cedecea, and Hafnia spp.; and "delayed" catalase reactors, comprising Escherichia, Shigella, Klebsiella, Enterobacter, Salmonella, Citrobacter, Edwardsiella, Kluyvera, and Tatumella spp.. In the present study, 144 E. tarda strains were classified either as "immediate" or "delayed" catalase reactors. This fact suggests that the groups 1 and 2 might be phylogenetically distant.

RFLP analysis of the 16S rDNA indicated genetic variation between $E$. tarda strains which had been assigned to groups 1 and 2. Furthermore, RFLP also suggested that the strains comprising of group 1 were subdivided into genotypes A and B. The strains isolated from diseased Japanese eel, Japanese flounder, loach, and ayu belonged to genotype $\mathrm{A}$, whereas the strains isolated from red sea bream and tilapia belonged to genotype B. Because of the conservative nature of the $16 \mathrm{~S}$ rDNA, its comparison in its structure have been an essential tool for understanding phylogenetic and evolutionary relationships among bacteria (Weisburg et al., 1991). The differences in the 16S rDNA genotype recorded here suggest that $E$. tarda might be subdivided into several subspecies.

The typing methods used in the current study were able to distinguish the strains that were isolated from diseased fish (group 1). Group 1 contained all of the strains which had high virulence to fishes and the strains classified into serotype A, whereas group 2 contained the low virulent strains and the strains classified into serotype B and C (Park et al., 1983, lida and Wakabayashi, 1990). Hence, the occurrence of edwardsiellosis in Japan might be caused by the population identified as group 1. In other words the strains of group 2 might not be involved in the occurrence of this disease. Recently, Itou et al. (1997) reported that $\mathrm{H}_{2} \mathrm{O}_{2}$ played an important role in the bactericidal processes of Japanese eel neutrophils, and that catalase inhibited their bactericidal activities. Indeed, it was demonstrated that strong catalase activities provided pathogens with resistance against the bactericidal activities of neutrophils and macrophages. Because the catalase activities of group 1 strains were higher than those of group 2, catalase activities of E. tarda might contribute as one of the virulence factors against fish.

Further studies are in progress on the sequencing of the 16S rDNA and the FeSOD gene to clarify the genetic differences and the phylogenetic distance among E. tarda populations, and the role of catalase for the pathogenicity is also investigating. 


\section{Acknowledgements}

We are grateful to Dr. I. Hirono (Tokyo University of Fisheries), Dr. T. Iida and Dr. T. Yoshida (Miyazaki University), who kindly provided the strains and to Dr. Andrew Bell (Tokyo University of Fisheries) reviewing the manuscript.

\section{References}

Aoki, T., I. Hirono and A. Hayashi (1995): The fish-pathogenic bacterium, Pasteurella piscicida detected by the polymerase chain reaction. The Proceedings of the 2nd Symposium on Diseases in Asian Aquaculture - "Aquatic Animal Health and the Environment" Fish Health Section, Asian Fisheries Society, Manila, Philippines.

Beauchamp, C and I. Fridovich (1971): Superoxide dismutase: improved assays and an assay applicable to acrylamide gels. Anal. Biochem., 44, 276-287.

Chester, B. and Lee B. Moskowitz (1987): Rapid catalase supplemental test for identification of members of the family Enterobacteriaceae. J. clin. Microbiol., 25, 439-441.

Clare, D. A., M. N. Duong, D. Darr, F. Archibalt, and I. Fridovich (1984): Effects of molecular oxygen on detection of superoxide radical with nitroblue tetrazolium and on activity stains for catalase. Anal. Biochem., 140, 532-537.

Crapo, J. D., J. M. McCord and I. Fridovich (1978): Preparation and assay of superoxide dismutase. Methods Enzymol., 53, 382-393.

Iida,T. and H.Wakabayashi (1990): Relationship between iron acquisition ability and virulence of Edwardsiella tarda, the etiological agent of paracolo disease in Japanese eel Anguilla japonica. In "The second Asian fisheries forum" (ed. by
R. Hirano and I. Honyu), AFS, Manila, 667-670.

Itou, T., T.Iida and H.Kawatsu (1997): The importance of hydrogen peroxide in phagocytic bactericidal activity of Japanese eel neutrophils. Fish Pathol., 32, 121-125.

Kubota, S. S., Kaige, N., Miyazaki, T. and Miyashita, T (1981): Histopathological studies on edwardsiellosis of tilapia-1. Natural infection. Bull. Fac. Fish., Mie Univ., 9, 155-165.

Kusuda, R., Toyoshita, T., Iwamura, Y. and Sano, H. (1976): Edwardsiella tarda from an epizootic of mullets (Mugil cephalus) in Okitsu Bay. Bull. Jap. Soc. Sci. Fish., 42, 271275.

Nakatsugawa, T (1983): Edwardsiella tarda isolated from cultured young flounder. Fish Pathol., 18, 99-101.

Park, S., H.Wakabayashi, and Y.Watanabe (1983): Serotype and virulence of Edwardsiella tarda isolated from eel and their environment. Fish Pathol., 18, 85-89.

Rashid, M. M., T.Mekuchi, T.Nakai, and K.Muroga (1994b): A serological study on Edwardsiella tarda strains isolated from diseased Japanese flounder (Paralichthys olivaceus). Fish Pathol., 29, 277.

Schmidt, T. M (1994): Fingerprinting bacterial genomes using ribosomal RNA gene and operons. Meth. Mol. Cell. Biol., $5,3-12$.

Selander, R. K, D. A. Caugant, H. Ochman, J. M. Musser, M. N. Gilmour, and T. S. Whittam (1986): Methods of multilocus enzyme electrophoresis for bacterial population genetics and systematics. Appl. Environ. Microbiol., 51, 873-884.

Wakabayashi, H. and Egusa, S. (1973): Edwardsiella tarda (Paracolobactrum anguillimortiferum) associated with pondcultured eel disease. Bull. Jap. Soc. Sci. Fish., 39, 931936.

Weisburg, W. G., S. M. Barns, D. A. Pelletier and D. J. Lane (1991): 16S ribosomal DNA amplification for phylogenetic study. J. Bacteriol., 173, 697-703. 